\title{
Treatment of transfusion requiring anemia in a Quick Diagnostic Unit integrated in an Emergency Department Setting
}

\author{
Charlotte Stenqvist*, Søren Wistisen Rasmussen, Thomas Andersen Schmidt \\ From Proceedings of the 5th Danish Emergency Medicine Conference \\ Aarhus, Denmark. 18-19 April 2013
}

\section{Background}

The establishment of a Quick Diagnostic Unit (QDU) in an Emergency Department (ED) setting has allowed expeditious blood transfusion of anaemic patients. The purpose of the study was to establish the mode of referral, describe the clientele, determine the underlying diseases and the $\mathrm{Hb}$ level of the referred patients.

\section{Methods}

Chart review of an 8 month period. Values were given as mean \pm SEM. Significance was evaluated using Student's two-tailed t-test for unpaired observations. The level of significance was $\mathrm{p}<0.05$.

\section{Results}

We found 108 patients. $71 \%$ was referred to hospital by their general practitioner and $18 \%$ of the patients came from oncological departments. In the given period we treated around 4 patients each week. 25 patients were admitted more than once, on average they came every 42 nd day. Two thirds of the patients only stayed for a few hours.

55 patients had a diagnosed cancer, 29 were men and 26 were women. 53 patients had a nonmalignant disease, 26 were men and 27 were women. The mean age for oncological patients was $73.8 \pm 1.3(\mathrm{n}=55)$ years and for nonmalignant patients $75 \pm 1.8$ years $(\mathrm{n}=53)(\mathrm{p}>0.6)$.

Oncological patients were given SAG-M transfusions at a $\mathrm{Hb}$ level of $5.0 \pm 0.09 \mathrm{mMol} / \mathrm{L}(80.4 \pm 1.4 \mathrm{~g} / \mathrm{L})$. Nonmalignant patients received SAG-M at a $\mathrm{Hb}$ level of $4.7 \pm 0.07 \mathrm{mMol} / \mathrm{L}(75.7 \pm 1.1 \mathrm{~g} / \mathrm{L})(\mathrm{p}<0.05)$.

* Correspondence: charlotte_stenqvist@hotmail.com

The Emergency Department, Holbaek University Hospital, Denmark
On average patients with malignant disease tended to receive less blod than patients with nonmalignant diseases $(\mathrm{p}=0.06)$, i.e. $2.2 \pm 0.1$ vs. $2.5 \pm 0.1$ SAG-M per contact. This however in clinical practice amounts to 2 SAG-M for both patient categories.

\section{Conclusion}

SAG-M transfusion may be given expeditiously in a QDU setting to elderly patients. On average oncological patients received SAG-M at a higher $\mathrm{Hb}$ level than other anemic patients. The transfusion tigger for patients with nonmalignant disease appears to comply with national guidelines.

Published: 9 September 2013

doi:10.1186/1757-7241-21-S2-A48

Cite this article as: Stenqvist et al:: Treatment of transfusion requiring anemia in a Quick Diagnostic Unit integrated in an Emergency

Department Setting. Scandinavian Journal of Trauma, Resuscitation and Emergency Medicine 2013 21(Suppl 2):A48.

Submit your next manuscript to BioMed Central and take full advantage of:

- Convenient online submission

- Thorough peer review

- No space constraints or color figure charges

- Immediate publication on acceptance

- Inclusion in PubMed, CAS, Scopus and Google Scholar

- Research which is freely available for redistribution 